\title{
2030 Sürdürülebilir Kalkınma Gündemi ve Engelliler: Güçlendirme Kavramı Çerçevesinde Bir Değerlendirme
}

\author{
The 2030 Agenda for Sustainable Development and People with Disabilities: An \\ Evaluation within the frame of Concept of Empowerment
}

\begin{abstract}
Şerafettin ERTEN *
$\ddot{O} Z$

Bu gün dünya genelinde bir milyardan fazla engelli bireyin bulunduğu tahmin edilmektedir. Engellilik yakın döneme kadar kişiye özel bir eksiklik, onarılması gereken tıbbi bir bozukluk olarak görülmüş̧ür. Ancak günümüzde engelliliğin toplumsal etkenlerden kaynaklanan bir kisitlllık hali olduğu kabul edilmektedir. Sosyal model olarak adlandirlan bu yaklaşım, engelliliği hak temelli bir anlayışla ele almaktadır. Bu bağlamda engellilerin yüzleştiği sorunların asıl nedenin temel insani hakların kullanılamaması olduğu kabul edilmektedir. Dolaylsıyla güçlendirme kavramına büyük önem atfedilmektedir. Bu yaklaşımın önemli özelliklerinden birisi de engellilerin kalkınmanın bir parçası olarak ele alınmasıdır. Günümüzde kalkınmanın bir süreç olduğu ve bu sürecin içerisinde sosyal, siyasal, kültürel, ekolojik vb. çok saylda boyut bulunduğu kabul edilmektedir. Illk kez 1968 yllında Roma Kulübü tarafindan dile getirilen bu görüş, Birleşmiş Milletlerce de kabul edilmişs ve özellikle 80'lerden sonra küresel ölçekte bir farkindalık yaratma çabası başlatılmıştır. Bu bağlamda atılan en son adım 2015 yılında kabul edilen Sürdürülebilir Kalkınma Hedefleri olmuştur. Hazırlanan belgede 2030 yllına kadar gerçekleştirilmesi planlanan, açlık ve yoksulluğu sona erdirmek, eşitsizlik ve adaletsizlikle mücadele, sağllkl yaşamın güvenceye alınması gibi on yedi hedef belirlenmiştir. Bu on yedi hedeften beşinde engellilere özellikle atıfta bulunulmaktadır. Bu çalışmada engellilerin güçlendirilmesi bağlamında, bu beş hedef değerlendirilmiştir. Sürdürülebilir Kalkınma Hedefleri içerisinde engellilere yapılan vurgu değerli bir kazanımdır. Ancak bu kazanımın somut politikalarla desteklenmesi gerekmektedir. Bu noktada politika yapıcılara büyük sorumluluk düşmektedir.
\end{abstract}

\section{ANAHTAR KELIMELER \\ Engellilik, Güçlendirme, Sürdürülebilir Kalkınma, Engelli Politikaları ABSTRACT}

Today, it is estimated that there are more than one billion people with disabilities around the world. Until recently, disability has been seen as a personal deficiency and a medical disorder that needs to be repaired. But, today, it is accepted that disability is a situation of limitation caused by social factors. This approach, called the social model, handle the disability with a rights-based understanding. In this context, the non-exercise of basic human rights is acknowledged as the main cause of primary problems of faced people with disability. Therefore, great importance is attributed to the concept of empowerment. One of the important features of this approach is that disabled people are handled as a part of development. Today it is accepted that development is a process and there are a large number of dimensions in this process like social, political, cultural, ecologic and so on. This opinion, first expressed by the Club of Rome in 1968, was accepted by the United Nations also and especially after the 80s, an effort was started to create awareness on a global scale. The last step taken in this context was the Sustainable Development Goals accepted in 2015. In this document, seventeen goals which are planned to be realized by 2030, such as ending hunger and poverty, struggling inequality and injustice, and securing healthy living have been determined. In the five of these seventeen goals, specifically has been referred to people with disabilities. In this study, these five objectives were evaluated in the context of empowerment of people with disabilities. The emphasis on disabled people within the Sustainable Development Goals is a valuable achievement. However, this achievement needs to be supported by concrete policies. At this point, policy makers have great responsibility.

\section{KEYWORDS}

Disability, Empowerment, Sustainable Development, Disability Policies

\begin{tabular}{|c|c|c|}
\hline \multicolumn{2}{|r|}{$\begin{array}{c}\text { Makale Geliş Tarihi / Submission Date } \\
\text { 19.09.2019 }\end{array}$} & $\begin{array}{c}\text { Makale Kabul Tarihi / Date of Acceptance } \\
\text { 26.11.2019 }\end{array}$ \\
\hline Attf & $\begin{array}{l}\text { Erten Ş.. (2019). } 2030 \text { Sürdürülebilir } \\
\text { Değerlendirme. Selçuk Üniversitesi So: }\end{array}$ & $\begin{array}{l}\text { Engelliler: Güçlendirme Kavramı Çerçevesinde Bir } \\
\text { ksekokulu Dergisi, } 22 \text { (2), 890-902. }\end{array}$ \\
\hline
\end{tabular}

\footnotetext{
* Dr. Öğr. Üyesi, Uşak Üniversitesi, serafettin.erten@usak.edu.tr, ORCID: 0000-0003-0297-0580,
} 


\section{GíRiș}

Günümüzde engellilik kavramı, sosyal ideallerin, kurumsal yapıların ve ulusal ve uluslararası politikaların karmaşık ilişkilerinin ortasında yer alan bir olgudur. İş göremezlik, dezavantaj, eksiklik, normal başarıyı kısıtlayan fiziksel veya zihinsel bir bozulma, engelleyen veya diskalifiye eden bir şey vb. tüm bunlar engellilik için kullanılan karşılıklardır, ancak bunlardan daha da önemlisi engelliliğin her şeyden önce bir kimlik işareti olarak anlaşılmasıdır (Linton, 2006: 162).

$\mathrm{Bu}$ algının iki önemli sonucu bulunmaktadır. Birincisi bu işareti taşıyan insanlar ayrı bir grup olarak kategorize edilmekte ve bu da onların toplumda, ekonomide, kültürde ve politikada marjinalleşmelerine neden olmaktadır. İkincisi ise sosyal ilişkiler ve yapılardaki çeşitlilik içerisinde engelliler büyük bir azınlık grubu haline gelmektedir. Gerçekten de günümüzde engelliler küresel ve ulusal ölçekte büyük bir azınlık grubu olarak kabul edilmektedir (Gadacz, 1994; Davis, 2006; Thomas, 2008; Goodley, 2011; Muyinda ve Whyte, 2011).

Engelliler geçmişte olduğu gibi bu gün de yoksulluk, dışlanma, ayrımcılık gibi çok çeşitli sorunlarla yüzleşmek zorundadır. Mevcut sorunlara yönelik politika oluşturma konusundaki yaklaşımımızı ve içeriğini belirleyen ise engellilik anlayışımızdır (Drake, 1999: 13). Günümüzde engelliliğin sosyal bir yapı olduğu ve konuya haklar temelinde yaklaşılması gerektiği kabul edilmektedir. Bu bağlamda özgürleştirme, kendini gerçekleştirme, bağımsız yaşam, fırsat eşitliği gibi bir takım ilkeler önem kazanmıştır. Bunların başında da güçlendirme gelmektedir. Güçlendirme, yaşadıkları ayrımcılık deneyimlerine bağlı olarak, engellilerin bireysel ve kolektif hedeflere ulaşabilmeleri için çeşitlendirilmiş destek sistemleri, eylem stratejileri ve politikalarla temel haklarını kullanabilir hale getirilmesidir (Gadacz, 1994: 161).

Kavram, sadece engelliler için değil, aynı zamanda toplumdaki diğer dezavantajlı gruplar için de kullanılmakta ve bu grupların güçlendirilmesi de teşvik edilmektedir. Ancak engelliler için kavram çok daha farklı bir boyuta sahiptir ve çok daha fazla önem arz etmektedir (UN Department of Economic and Social Affairs, 2019c):

- Dünyada bir milyardan fazla kişi bir engellilik durumu ile yaşamaktadır. Bir başka ifade ile her yedi kişiden birisi engellidir.

- Bu engelli nüfusun \% 80'i az gelişmiş veya gelişmekte olan ülkelerde yaşamaktadır.

- Temel eğitimi tamamlayabilen engelli oranı gelişmekte olan ülkelerde \% 30 , gelişmiş olan ülkelerde \% 50'ler civarındadır.

- Sağlık hizmetlerinden yararlanamayan engellilerin oranı \% 60'ları bulmaktadır.

- İstihdama katılamayan engelli oranı \% 70’ler civarındadır.

- Dünyadaki yoksul nüfus içerisinde en yoksulların önemli bir bölümü yine engellilerdir.

Örnekler göstermektedir ki engelli olmak toplumdaki diğer bireylerden farklı olarak daha fazla ve daha büyük sorunlarla uğraşmak demektir. Engelliler tüm toplumda başta ekonomik olmak üzere, üretilen sosyal, siyasal ve kültürel zenginlikten en az pay alan kesimdir.

Günümüzde bu zenginlik, ekonomik büyüklük yanında temel hak ve özgürlüklerin korunması, hukukun işletilmesi, çevreye duyarlılık, sosyal adaletin sağlanması, kültürel farklılıkların yaşatılması, paylaşım biçimi gibi birçok unsurdan oluşan sürdürülebilir kalkınma kavramı ile açıklanmaktadır. Dolayısıyla kalkınmanın faydalarından büyük ölçüde dışlanmış olan engellilerin yeniden bu sürecin içinde yer alabilmeleri için güçlendirilmeleri gerekmektedir (Swartz ve MacLachlan, 2009: 4).

Birleşmiş Milletler (BM), 80'li yıllardan bu tarafa küresel çapta bir sürdürülebilir kalkınma gündemi ve stratejisi oluşturmaya çalışmaktadır. Yakın döneme kadar engelliler bu gündemin dolaylı bir parçası olarak görülmüştür. Ancak 2015 yılında ilan edilen "Dünyayı Dönüştürmek: Sürdürülebilir Kalkınma İçin 2030 Gündemi" adlı stratejide doğrudan engellilere de yer verilmiştir. Belgede yer alan 17 hedeften 5'inde özellikle engellilere vurgu yapılmıştır. Bu vurgunun bir göstergesi olarak 2018 yılı Dünya Engelliler Günü teması da "Engelli bireylerin güçlendirilmesi ve kapsayıcılı̆̆ın ve eşitliğin sağlanması" olarak belirlenmiştir (UN Department of Economic and Social Affairs, 2018).

Çalışmanın amacı da engelliler için son derece önemli bir kavram olan güçlendirme bağlamında engellilerle ilişkilendirilen sürdürülebilir kalkınma hedeflerinin değerlendirilmesidir. Çalışmada öncelikle engelliliğin günümüzde nasıl algılandığı açıklanmış; ardından güçlendirme kavramı ve engelliler için önemi ele alınmış ve devamında engellilere vurgu yapılan sürdürülebilir kalkınma hedefleri, güçlendirme kavramı çerçevesinde değerlendirilmiştir. Son bölümde ise sürdürülebilir kalkınmanın bir parçası olarak engellilerin güçlendirilmesi ile ilgili tespitlere ve önerilere yer verilmiştir. 
Engellilik alanına ilişkin Türkçe literatür taramasında doğrudan güçlendirme kavramını ele alan bir çalışmaya rastlanmamıştır. Sürdürülebilir kalkınma ve engellilik ilişkisi ile ilgili tek çalışma ise 2016 yılında Tekeli tarafından yapılmıştır. Bu bağlamda çalışmanın ilgili literatüre katkı sağlaması beklenmektedir.

\section{Engelliliği Anlamak}

Günümüz engelli çalışmaları incelendiğinde -medikal perspektif bir tarafa bırakılırsa- engelliliğin tanımlanmasından daha çok engelliliğin anlaşılması yönünde bir çaba olduğu görülmektedir. Bununla birlikte sosyal bir olgu olarak engelliliği kavrayabilmemiz için mutlaka bir tanıma ihtiyacımız bulunmaktadır. Bu bağlamda engellilik çalışmalarına yön veren iki ana eğilimden örnek vermek yerinde olacaktır. Medikal bir yaklaşımla engellilik, "doğuştan var olan ya da sonradan ortaya çıkan bir takım fiziksel, zihinsel, duyusal ve ruhsal kayıplar nedeniyle, bireyin yeteneklerinde ve iş yapabilme gücündeki sınırlılık ya da noksanlık halidir (WHO, 1993: 14; Burcu, 2007: 7)". Konuya sosyolojik açıdan yaklaşanlara göre ise engellilik, "toplumsal organizasyonların bireyleri engellilikleri nedeniyle ya yeterince ya da hiç dikkate almamaları sonucu ortaya çıkan ve onları toplumsal ilişki ve faaliyetlerin dışında bırakan bir dezavantaj veya kısıtlılık halidir (Drake, 1999: 13; Barnes ve Mercer, 2003: 11)".

Literatürde çok çeşitli ve sayıda tanım bulmak mümkündür. Ancak, hangi açıdan ele alınırsa alınsın medikal ya da sosyal-, karşımıza bir temel ortak nokta çıkmaktadır: Engellilik bir dezavantajlılık ve kısıtlılık halidir. Engelliler açısından bu durum ve yarattığı olumsuz sonuçlar geçmişten günümüze değişmiş değildir. Tedavi için kurumlara kapatılmak, bilimsel deneylerde kullanılmak, toplumdan dışlanmak, bozuk bir makine gibi onarılmaya çalışılmak, hor görülmek uğradıkları kötü muamelelerden sadece birkaçıdır. Dolayısıyla bunlar ve benzeri nedenlerden ötürü engelliler tarihi süreç içerisinde, tüm toplumlarda daima ezilen ve bask1 altında tutulan azınlık gruplardan birisi olmuştur (Davis, 2006: xv).

Engellilerin maruz kaldıkları kötü muamele ve sorunları değişmemekle birlikte, engelliliğe yönelik bakış açısı ve algının bu süreç içerisinde değiştiği görülmektedir. Yirminci yüzyılın ikinci yarısı bu bakımdan bir dönüm noktası olmuştur. Daha önceki dönemlerde engellilik bireyi ilgilendiren ve ona özgü ilahi bir ceza, ahlaki bir yozlaşmışığıın sonucu, bir trajedi, biyolojik, fizyolojik veya ruhsal bir kusur ya da anormallik olarak değerlendirilirken; 1960'lı yıllarla birlikte başlayan engellilik hareketleri sosyal baskıya, kültürel söylemlere ve çevresel kısıtlamalara dikkat çekmiştir (Shakespeare, 2006; Ghosh, 2012).

Engelli hareketleriyle birlikte gelişen yeni algı yoğun bir ilgi ve talep görmüştür. Çünkü engellilik alanında uzun bir süre geçerliliğini koruyan medikal yaklaşım, engelli bireyler ile toplumdaki diğer bireyler arasında bir ast-üst ilişkisi kurmuştur. Burada üstten kasit engelli bireyler üzerinde otorite ve güç sahibi olan herkestir. $\mathrm{Bu}$ ilişki empoze edilen tanımlamalar, çevrenin kontrolü ve engellilerin ihtiyaçlarına uygun görülen tedavi türlerinin, hizmetlerin, olanakların ve programların tek taraflı olarak belirlenmesi ile kendini göstermiştir (Gadacz, 1994: 5). Sonuç olarak ortaya konulan uygulama ve değişiklikler, engellilerin sorunlarına çözüm bulma ve ihtiyaçlarını karşılamaya yönelik olarak sosyal ve fiziksel dokunun değiştirilmesinden ziyade, mevcut sosyal normları ve kurgulanmış çevreyi bozmayacak şekilde gerçekleşmiştir (Drake, 1999: 10).

Oysa engelliler de toplumdaki her birey gibi bir "işlev görmek" istemektedir. Bunun anlamı kendilerini tanımak, engelleri ile yaşamayı öğrenmek, yapabileceklerini kabul etmek ve ellerinden geldiğince bunu sürdürmektir. Talepleri, tüm bunları yardıma bağımlı oldukları insanların egemenliğini hissetmeden ve dişlanma ve utanma duygusu olmadan yerine getirebilmektir (Siebers, 2006: 179). Engelli hareketleri de bu talepler doğrultusunda, baskı ve dışlanmaya bir meydan okuma ve aşırı bireysel ve tıbbi anlayışa bir başkaldırı olarak başlamıştır (Shakespeare, 2006: 197).

Bu başkaldırının en somut adımı, engelli aktivistler tarafından kurulan Ayrımcılığa Karşı Fiziksel Engelliler Birliği (Union of The Physically Impaired Against Segregation-UPIAS) adlı örgütün 1976 yılında yayımladığı "Engelliliğin Temel İlkeleri” adlı bildiri ile atılmıştır. UPIAS bildiride engelliliğin biyolojik ve sosyal alanları arasındaki farkı ortaya koyarak, sosyo-politik bir engellilik yaklaşımını benimsemiştir. Buna göre engelliler sosyal açıdan baskı altına alınmış bir gruptur. Bu baskı onların fiziksel sakatlıklarından dolayı değil, toplumsal etkenlerden kaynaklanan bir dezavantajlllık durumundan ileri gelmektedir. Bu kabul ile örgüt engelliliğin sosyal modelinin temelini atmıştır (UPIAS, 1976: 3; Barnes, 2012: 13).

Sosyal modelin merkezinde engellilik deneyimi yer almaktadır. Bu deneyim aile ortamı, gelir ve maddi destek, eğitim, istihdam, barınma, ulaşım, kurgulanmış çevre gibi çok çeşitli sosyal ve maddi unsur ve koşulu kapsamaktadır (Barnes ve Mercer, 2006: 37). Tüm bedenler toplumsal olarak inşa edilmiştir ve bu inşada sosyal tutum ve kurumların etkisi bedenin biyolojik gerçekliğinden daha baskındır (Siebers, 2006: 173). Dolayısıyla toplumun değerleri, normları, örgütlenme şekli, mimarisi, yasaları ve kurumları gibi yapılar ve bunların etkisi engelliliğin ortaya çıkmasında baş aktörlerdir. (Drake, 1999: 13). 
Engelliliğin sosyo-politik bir kategori olarak tanımlanması, doğal olarak ortak ve farklı koşul ve deneyime sahip yeni bir toplumsal grubu da kabul etmek demektir (Linton, 2006: 163). Bu grup toplumun eşit ve bağımsız fertleri olarak, diğer bireyler gibi kendi kararlarını alabilme, benzer risklere girebilme, aynı saygıyı görebilme ve bağımsız ve kaliteli bir yaşam sürebilme talebinde bulunmaktadır (Brisenden, 1986: 177). Güçlenerek artan bu talepler sosyal modele yeni bir perspektif kazandırmış ve 80'li yıllardan itibaren engellilik bir temel hak ve özgürlükler konusu olarak ele alınmaya başlanmıştır (Bagenstos, 2009: 20).

Hak temelli yaklaşımın temel savı şudur: Engelliler, temel insani haklardan yararlanamadıkları için toplumun diğer bireylerinden daha düşük bir yaşam kalitesine katlanmaktadır. İnsan haklarının, evrensel ve herkes için geçerli olduğu prensibi göz önüne alındığında; engellilerin de diğer bireyler gibi bu haklardan sonuna kadar yararlanabilmesi gerekmektedir (Cooper, 2000: 59). Bu nedenle temel amaç, engellilerin toplum içerisinde bağımsız bir şekilde yaşamalarını ve kendilerini gerçekleştirebilmelerini sağlamak olmalıdır (Beaulaurier ve Taylor, 2007: 54). Ortaya konulan bu yeni yaklaşım çerçevesinde, birbirleri ile sıkı sıkıya bağlı olan güçlendirme, bağımsız yaşam, yaşam kalitesi, kendini gerçekleştirme gibi kavramlar önem kazanmıştır.

Engelliliğin insan hakları çerçevesinde ele alınması, kısa süre içerisinde engellilik alanının hâkim anlayışı haline gelmiştir. $\mathrm{Bu}$ bağlamda başta uluslararası alan olmak üzere, bu gün engellilere yönelik politikalar engellilerin firsat eşitliği, bağımsız yaşam, sosyal refah, sosyal adalet, vatandaşlık, erişebilirlik, sosyal ve ekonomik dâhil olma gibi bir takım ilkeler çerçevesinde pasif-tüketici konumdan, aktif-üretici konuma geçmelerini, bir başka ifadeyle güçlendirilmelerini amaçlamaktadır.

\section{Engelliler Açısından Güçlendirme Kavramının Anlamı}

Azgelişmişlik, yoksulluk, ayrımcılık, erişememe ve bir de bunun üzerine toplumda engellilere yönelik olumsuz varsayım ve tutumlar eklendiğinde, engellilerin sosyal, ekonomik, kültürel, siyasal vb. yapılardan dışlanmaları kaçınılmaz olmaktadır. Dışlanma doğal olarak marjinalleşme eğilimini de beraberinde getirmektedir (Shakespeare ve Watson, 2001: 553; Jaeger ve Bowman, 2005: 10; Goodley, 2011: 1).

60'lı yıllardan itibaren bu eğilim, engelli hareketlerinin ve savunuculuğunun beslendiği ana kaynaklarından birisi olmuş ve kimlik tabanlı bir siyasetin önünü açmıştır. Sosyal-yapısalcı bir temele dayanan kimlik siyaseti, engelli ayrımcılığını, ırkçılık, cinsiyetçilik vb. diğer toplumsal ayrımcılık durumları ile aynı görmüştür (Pfeiffer, 2007: 9). Buna paralel olarak engelliler bir kültürel azınlık kabul edilip, temel hak ve özgürlükleri elde etme hususunda dini cemaatler, etnik gruplar ve LGTB hareketleri gibi sosyal kimlik tabanli grup ve hareketlerle birlikte ele alınmıştır (Lee, 2005: 90). Bu bağlamda güçlendirme kavramı diğer marjinal grup hareketlerinden devşirilerek engellilik hareketi ve çalışmalarının önemli bir parçası haline gelmiştir (Siebers, 2006: 200). Özellikle sosyal model, engelliliği bir güçlendirme ve haklar sorunu olarak vurgulamada ve kamu ve siyasal desteği sağlamada uluslararası düzeyde güçlü bir etkiye neden olmuştur (Barnes, 2012: 18; Beresford, 2012: 162).

Güçlendirme engellilik dışında da farklı alanlarda ele alınıp, içi doldurulmaya çalışıldığından anlamı tam netleştirilememiş bir kavramdır, ancak temelde güç ve güçsüzlük arasındaki tartışmaların ortasında yer almaktadır (Fazil vd., 2004: 390). Güçlendirme öncelikle bir tür gücün yaratılması ve edinilmesi sürecine işaret etmektedir (Charlton, 2000: 123). Bu, insanların kendi yaşamları üzerinde kontrol kazanmalarına yardımc1 olan çok boyutlu, sosyal bir süreçtir. Dolayısıyla en genel ifadeyle bireylerin kendi yaşamlarında, çevrelerinde ve toplumda, önem atfettikleri konularda faaliyette bulunabilmeleri için gücün geliştirilmesi olarak tanımlanabilir. Bu noktada vurgulanması gereken husus güçlendirmenin aynı zamanda uygulayabilme veya uygulamaya koyabilme kapasitesini işaret etmesidir (Page ve Czuba, 1999).

Güçlendirme, sosyal yapı ve insan unsuru arasındaki ilişkiler ile güç ve güçsüzlük arasındaki bağlantı çerçevesinde de farklı ele alınan bir kavramdır. Yapısalcı bakış açısına göre, güçsüzlük yapısal eşitsizliklerin bir sonucudur ve güçlendirme temel olarak bireylerin ve toplulukların tam potansiyellerini gerçekleştirmelerini kısıtlayan sosyal, ekonomik ve kurumsal engelleri ortadan kaldırmaya yönelik bir eylemdir. Buna karşılık, insan unsuru yaklaşımı, bireylerin bilinçli ve özerk davranma yeteneklerine odaklanmaktadır. Güçsüzlük, bireyin kişisel tercihini ya da kendini gerçekleştirmesini engelleyen bir benlik, bir yabancılaşmadır. Dolayısıyla güçlendirme bu benlik ve yabancılaşmanın ortadan kaldırılmasına odaklanmalıdır (Fazil vd., 2004: 390). Bu bakış açısıyla, güçlendirme verilen bir şey değil, insanların kendileri için yapması gereken bir şeydir. Buradaki önemli nokta ise sahiplenmedir (Barnes, 2004: 52). Bir başka ifadeyle bireyin bunu talep etmesi ve bu talebin yerine getirilmesi için çaba sarfetmesi gerekmektedir.

Engellilik alanında güçlendirme mevcut sorunların çözümüne yönelik ilk akla gelen araçların başında yer almaktadır (Ingstad ve Eide, 2011: 7). Aynı zamanda engelli bireyin toplumsal ve kamusal alanda hareket etmesini sağlamaktadır (Hansen ve Sait, 2011: 99). Bu nedenle bir gelişim ve dönüşüm süreci olarak, engelli

Selçuk Üniversitesi Sosyal Bilimler Meslek Yüksekokulu Dergisi, Yıl: 2019 Cilt: 22 Sayı:2 
hareketlerinin de merkezinde bulunmaktadır. Çünkü kazanımlar elde etmenin başlıca yolu kendi sosyal ve politik çevrelerini inşa etmiş, bilinçli ve eylem becerileri yüksek, güce sahip üyelerden geçmektedir (Gadacz, 1994: 95).

Engellilik literatürü incelendiğinde güçlendirme kavramının, bağımsız yaşam, yaşam kalitesi, engelli hakları, kendini gerçekleştirme, özgürleştirme gibi çok sayıda kavramla birlikte ele alındığı ve ilişkilendirildiği görülmektedir (Gadacz, 1994; Charlton, 2000; Shakespeare ve Watson, 2001; Stainton, 2005; Barnes ve Mercer, 2006; Griffiths vd., 2009).

Gerçekten de tüm bu kavramlar güçlendirme yaklaşımının bir parçası olarak onu tamamlamakta, onun içeriğini oluşturmaktadır. Özgürleştirme ile toplumsal engellerin açığa çıkarılması, engellilik algılarının değiştirilmesi ve politik eylemin oluşturulması ifade edilmektedir (Barnes ve Mercer, 2006: 56). Kendini gerçekleştirme ya da kendi kaderini tayin etmek, engelli bireyin her şart ve durumda kendi seçimi olan faaliyetleri yapabileceği bir konuma gelmesidir (Gadacz, 1994: 86). Haklar bağlamında ele alındığında, engelli bireylerin taleplerini dile getirebilmeleri, bu talepleri gerçekleştirmek için gerekli desteğin verilmesi, kaynaklara erişimin sağlanması ve tüm karar verme sistemleri içerisine engellilerin dahil edilmesini içermektedir (Stainton, 2005: 292). Yaşam kalitesi bağlamında, toplumun tüm diğer bireyleri gibi engelliler için de asgari düzeyde kabul edilebilir bir yaşam için zorunlu olan ekonomik, politik ve sosyal standartların oluşturulması anlamını taşımaktadır (Charlton, 2000: 121).

Konunun teorik kısmı ve bununla ilgili tartışmalar bir tarafa, asıl üzerinde durulması gereken güçlendirme yaklaşımının uygulamaya aktarılabilmesidir. Bu noktada ulusal ve uluslararası olmak üzere iki boyuttan söz edilebilir.Ulusal boyutta her ülke kendi şartlarına göre farklı strateji ve politika uygulamalarına yönelmektedir. Bunlar arasında engellilerin bir takım haklarını kullanabilmeleri için yasal düzenlemeler yapma, engellilerin eğitim ve istihdamını teşvik edip destekleme, bir takım sosyal güvenlik programları oluşturma, erişebilirliği sağlama, engellileri ve engelli savunucusu kurum ve kuruluşları karar alma süreçlerine dahil etme ve toplumun engelli algısını değiştirmeye yönelik faaliyetler gerçekleştirme sayılabilir (Ingstad ve Eide, 2011: 7; Griffiths vd., 2009: 113).

Uluslararası boyutta ise evrensel bir takım ilkeler oluşturulması ve bunların hayata geçirilmesi için yürütülen programlar karşımıza çıkmaktadır. Bir çok alanda olduğu gibi engellilik alanında da uluslararası politikalar üreten asli kurum BM'dir. BM 1975 yılında İnsan Hakları Evrensel Beyannamesi'ne ek olarak yayınladığı Engelli Hakları Bildirgesi'nden bu tarafa yaptığı çalışmalarla bir taraftan engelliliği daha görünür kılarken, diğer taraftan da engelliliğin bir temel hak ve özgürlükler alanı olarak kabul edilmesine katkıda bulunmuştur (Shakespeare ve Watson, 2001: 553).

2006 yılında kabul edilen Engelli Haklarına İlişkin Sözleşme (EHS) ise bu süreçte atılan en büyük ve önemli adımdır. Belge günümüzde engellilik alanında yararlanılan temel kılavuz ve kaynak olarak kabul edilmektedir. Bunun yanında sözleşme ulusal ve uluslararası platformda güçlendirme ve yenilikçi politikalar oluşturmak için eşsiz bir araç işlevi görmektedir (Bickenbach, 2012: 59). Sözleşmenin genel felsefesi engellilerin hak ve özgürlüklerinin korunması ve güçlendirilmesidir (BM, 2006). Bu çerçevede ortaya konulan sorumluluklar taraf devletleri bağladığı gibi, doğal olarak sözleşmeyi hazırlayan BM'yi de bağlamakta ve onun tarafindan oluşturulan ve yürütülen tüm diğer çalışmalar, programlar ve stratejileri de kapsamaktadır.

Birleşmiş Milletler Kalkınma Programı'nın (UNDP), 2015 yılında ilan ettiği Sürdürülebilir Kalkınma Hedefleri'ni (SKH) de bu kapsamda ele almak gerekir. BM, Engelli Hakları Sözleşmesi'nde kabul ettiği güçlendirme yaklaşımını engellileri kalkınmanın bir parçası olarak kabul etmekle ve onlara hedefler içerisinde ayrıca yer vermekle uygulamaya aktarmış olmaktadır.

\section{Sürdürülebilir Kalkınma Kavramı ve Engellilik}

Her ülke zenginleşmeyi ve refaha kavuşmayı, her devlet güçlü ve itibar sahibi olmayı ve her birey de yaşam kalitesini en üst düzeye çıkarmayı arzular. Yakın döneme kadar bu arzuların sadece ekonomik güçle ilişkili olduğu kabul edilmiştir. Ancak birey, bireylerden oluşan toplum, bu toplumu yöneten devlet ve hepsinin içinde bulunduğu mekân birbirleri ile kopmaz bağlardan oluşan bir ilişkiler ağı içerisinde varlığını sürdürür ve ekonomi bu ilişkiler ağının ortaya çıkardığı yapılardan sadece bir tanesidir. Bu nedenle günümüzde zenginlik, refah, güç, itibar ve iyi bir yaşam gibi olguların ölçüsü olarak sadece ekonomik duruma bakılmamakta, bunun yanına temel hak ve özgürlükler, çevre, eğitim, sağlık, beslenme gibi çok sayıda faktör de eklenmektedir. Bu anlayış, UNDP tarafından oluşturulan çeşitli politika belgeleri ve gerçekleştirilen faaliyetler ile "sürdürülebilir kalkınma" adı altında küresel ölçekte hayata geçirilmeye çalışılmaktadır. Sürdürülebilir kalkınma tüm insanlığın esenlik ve refahının evrensel bir takım ilkeler çerçevesinde gerçekleştirilme çabasıdır. Elbette engelli bireyler de bunun önemli bir parçası olarak görülmektedir. 


\subsection{Ekonomik Büyümeden Sürdürülebilir Kalkınmaya}

Sürdürülebilir kalkınmanın mantığını anlayabilmek için öncelikle ekonomik büyümeyi ele almak gerekmektedir. Çünkü uzun bir süre ekonomik büyüme zenginliğin temel göstergesi olarak kabul edilmiştir. Ekonomik büyüme en genel ifadeyle, bireylerin talep ettikleri mal ve hizmetlerin karşılanması için ülkenin üretim yetenekleri ve kapasitesinin geliştirilmesidir (Peterson, 1994: 480). Sanayi devrimi ile başlayan klasik ekonomik büyüme anlayışı üretim bağlamında sadece nicelik, yani miktar olarak bir artışa vurgu yapmıştır. $\mathrm{Bu}$ yaklaşım ekonomi içerisindeki fiziki değişimleri dikkate alırken, diğer unsurları göz ardı etmiştir (Berber, 2006: 6). Bu bakış açısından ekonomik büyümeyi belirli bir zaman dilimi içerisinde-ki genellikle bir yıl olarak kabul edilir- kişi başına düşen mal ve hizmet miktarı olarak ifade etmek de mümkündür. Bunun ekonomik olarak karşılığı, gayri safi milli hasılanın ve buna bağlı olarak kişi başına düşen gelirin artmasıdır (Peterson, 1994: 481). Zamanla bir ideoloji haline dönüşen büyüme, refah ve esenliğin kaynağı olarak kabul edilmiş ve hatta bir ülkedeki sosyal, ahlaki, çevresel vb. sorunların çözümü için bir ön koşul olarak görülmüştür (Haapanen ve Tapio, 2016: 3501).

Bu algı bir noktaya kadar doğrudur. Çünkü ekonomik büyüme toplumsal sorunları çözme potansiyelini artırmaktadır. Ancak tarihsel süreç incelendiğinde büyümenin, daha fazla eşitsizlik, daha yüksek işsizlik, zayıf demokrasi, kültürel kimlik kaybı veya gelecek nesillerin ihtiyaç duyduğu doğal kaynakların aşırı tüketilmesi pahasına gerçekleştirildiği görülmektedir. Bununla birlikte ekonomik büyümenin her koşulda bireysel refahı ve yaşam kalitesini artırmadığı da bir gerçektir (Soubbotina, 2004: 8).

1968 yılında on ülkeden farklı bilim insanı tarafından kurulan Roma Klübü kontrolsüz ekonomi büyümenin yol açtığı sorunları tespit etmek ve çözüm önerileri getirmek amacıyla "İnsanlığı Tehdit Eden Sorunlar" adlı projeyi başlatmıştır. Proje kapsamında elde edilen ilk veriler ışı̆̆ğında 1972 yılında "Ekonomik Büyümenin Sınırları" raporu açıklanmıştır. Raporda küresel ölçekte kontrolsüz büyüme, nüfus artış hızı, çevre kirliliği ve sanayileşme gibi sorunlara çözüm bulunmadığ 1 takdirde insan oğlunun varlığını çok uzun sürdüremeyeceği ifade edildikten sonra; çözüm önerisi olarak dünya yüzeyinde her bireyin temel maddi ihtiyaçlarına doyumunu sağlayacak ve her bireyin beşeri potansiyelini geliştirmesi için eşit firsata sahip olmasına olanak verecek sürdürülebilir bir ekonomik ve ekolojik dengenin kurulması gerektiği belirtilmiştir (Meadows vd., 1972). Roma Kulübünün bu girişimi ile büyümeye ilişkin tartışmalar ve sürdürülebilirlik kavramı uluslararası alana taşınmıştır.

Ekonomik Büyümenin Sınırları Raporu'na paralel olarak, aynı yıl BM'nin düzenlediği Çevre ve Kalkınma Konferansı'nın sonuç bildirgesinde de çevrenin korunması ve geliştirilmesinin refah ve kalkınma açısından en başta gelen sorunlardan birisi olduğu kabul edilmiş ve çevreye duyarlı bir kalkınma modelinin geliştirilip benimsenmesi, planlı kalkınmaya önem verilmesi, uygulanacak politikalarda temel hak ve hürriyetlerin gözetilmesi gibi ilke kararlar alınmıştır (BM, 1973). 1980 yılında hazırlanan Dünya Korunma Stratejisi'nde " sürdürülebilir kalkınma" kavramı ilk kez dile getirilmiş ve 1987 yılında Dünya Çevre ve Kalkınma Komisyonu (WCED) tarafından hazırlanan "Ortak Geleceğimiz” adlı raporda da yine ilk kez tanımlanmıştır (Adams, 2009: 59).

Brundtland Raporu olarak da adlandırılan belgede sürdürülebilir kalkınma "gelecek nesillerin kendi ihtiyaçlarını karşılayabilme kabiliyetinden ödün vermeden, bugünün ihtiyaçlarını karşılayan bir kalkınma" olarak tanımlanmıştır. Yine rapora göre sürdürülebilir kalkınma iki temel kavramı içerir: Birincisi dünyanın en yoksul kesiminin öncelikli olarak karşılanması gereken temel ihtiyaçları bağlamında "ihtiyaçlar"; ikincisi ise çevrenin bu günkü ve gelecekteki ihtiyaçları karşılama kabiliyeti konusunda teknoloji ve sosyal organizasyonların getirdiği "sınırlamalar" (WCDE, 1987).

Raporda ayrıca büyümenin temel ihtiyaçların karşılanması noktasında gerekli olduğu, ancak bu ihtiyaçların karşılanamadığı yerlerde ekonomik büyümenin tek başına yeterli olmadığı belirtilmiştir. Çünkü dünyanın özellikle az gelişmiş ve gelişmekte olan bölgelerinde büyüme ekonomik aktivitenin artması yanında yoksulluk ve çevre kirliliğini de beraberinde getirmektedir. Bu nedenle bir taraftan toplumların üretken kapasitelerini artırırken diğer taraftan da herkes için adil firsatlar sağlayarak bireylerin ihtiyaçlarını karşılamak için sürdürülebilir bir kalkınma yolu seçilmelidir (WCDE, 1987).

Ancak sürdürülebilir kalkınma biyolojik, ekonomik ve sosyal olmak üzere üç farklı sistemin etkileşimi ve birbirleri ile alış verişlerinden oluşmaktadır. Bu sistemlerin amaçları ve hedefleri farklıdır ve çoğu zaman bunların uyumlaştırılması ve bir optimum noktaya ulaşılması gerekmektedir (Barbier, 1987: 104). Bu nedenle 1987 'den bu tarafa BM, küresel bir uzlaşmanın sağlanması, ortak politikaların belirlenmesi ve uygulamaların izlenmesi adına çok sayıda faaliyette bulunmuştur. Sürdürülebilir kalkınma bağlamında, bunların başında UNDP tarafından ortaya konulan ve ölçülen "insani gelişim” kavramı gelmektedir. 
Sürdürülebilir kalkınmanın temel savlarından birisi gelecek nesillerin çıkarlarının da bu günkü neslin çıkarları ile aynı ölçüde dikkate alınması gerektiğidir. Bunun anlamı bu gün yaşan neslin refah ve mutluluğunu gelecek neslin yoksulluk ve mutsuzluğu üzerine kuramayacağınızdır. Konunun bir başka yönü de sürdürülebilir bir kalkınma ve ekonomik büyüme için mutlaka insan sermayesinin geliştirilmesi ve güçlendirilmesi gerektiğidir. Çünkü insanoğlu bu süreçte hem temel araç, hem de temel amaç konumunda bulunmaktadır (Anand ve Sen, 1994; Anand ve Sen, 2000; Streeten, 1994). Dolayısıyla kalkınmanın amacı insanların durumlarını geliştirmek olmalıdır. Bu gelişim sadece gelir ve refahı artırmak anlamına gelmemektedir. İnsanlara daha sağlıklı bir yaşam, bilgiye ulaşım imkanı, iyi bir eğitim, kişisel güvenlik, politik katılım, toplumsal içerme, güvenceye alınmış temel hak ve özgürlükler gibi olanaklar da sunulmalıdır (UNDP, 1990: 9).

Sürdürülebilir kalkınma bağlamında atılan bir diğer önemli adım 2000 yılında ilan edilen Bin Yıl Kalkınma Hedefleri'dir (BKH). Bu hedefler de BM'nin insanlığın sorunlarının çözümü için küresel ölçekte ilke ve politikalar belirleme çabalarının bir diğer örneğidir. 189 ülke, küresel düzeyde insanlık onuru, eşitlik ve esenlik ilkelerinin güçlendirilmesi adına taşıdıkları sorumluluğu kabul ederek bu bildirgeyi imzalamıştır. Belgede, aşırı yoksulluk ve açlığın ortadan kaldırılması, evrensel ilköğretimin geliştirilmesi, cinsiyet eşitliğinin sağlanması ve kadınların güçlendirilmesi, çocuk ölümlerinin azaltılması, anne sağlığının iyileştirilmesi, HIV/AIDS ve diğer salgın hastalıklarla mücadele edilmesi, çevresel sürdürülebilirliğin sağlanması ve kalkınma için küresel bir ortaklık geliştirilmesi olmak üzere 8 hedef ve bu hedeflere bağlı olarak 21 amaç belirlenmiştir. Yine belgede bu amaçların 2015 yılına kadar gerçekleştirilmesi de öngörülmüştür (BM, 2000).

BKH'nin uygulanması ve alınan sonuçlar çeşitli tartışmalara neden olmuştur. Özellikle belirlenen hedeflerdeki ilerlemenin dünyada bölgesel olarak farklılaştığ 1 ve hedefler arasında bir dengenin kurulamadığı vurgulanmıştır. Bunun nedeni olarak ülkelerin genellikle bu hedeflerin tamamına değil, bazılarına yoğunlaşması gösterilmiştir. Bu da gelişmiş ve gelişmekte olan ülkeler ayrımını gündeme getirmiş ve hedeflerin gelişmiş ülkeler tarafından gelişmekte olanlara yönelik uygulanan bir reçete olarak algılanmasına yol açmıştır (ICLEI, 2015).

Yapılan eleştiriler bir tarafa, BKH'nin uygulamaya konulmasından sonra bir milyardan fazla insanın aşırı yoksulluk, açlık, salgın hastalıklar ve eğitim gibi sorunlarında az ya da çok iyileşme sağlandığı gözlemlenmiştir. Getirilen eleştiriler, elde edilen olumlu sonuçlar ve insanların bu hedeflerin de ötesinde daha iyi bir gelecek için talepleri de göz önüne alınarak, 2012 yılında BM Rio+20 toplantısında, BKH üzerine inşa edilecek yeni bir gündem oluşturulmasına karar verilmiş ve bu bağlamda 2015 yılında "Dünyamızı Dönüştürmek: 2030 Sürdürülebilir Kalkınma Gündemi” başlığı altında yeni bir hedefler listesi kabul edilmiştir (UNDP, 2016; Gaffney, 2014).

Yeni belgede yoksulluğa son, açlığa son, sağlıklı bireyler, nitelikli eğitim, toplumsal cinsiyet eşitliği, temiz su ve sıhhi koşullar, erişilebilir ve temiz enerji, insana yakışır iş ve ekonomik büyüme, sanayi, yenilikçilik ve altyapı, eşitsizliklerin azaltılması, sürdürülebilir şehir ve yaşam alanları, sorumlu üretim ve tüketim, iklim eylemi, sudaki yaşam, karasal yaşam, barış ve adalet ve hedefler için ortaklıklar konu başlıklarında on 17 hedef ve bunlara bağlı 169 amaç belirlenmiştir. Belirlenen bu hedefler bağlamında 2030 yılına kadar, her yerde yoksulluk ve açlığın sona erdirilmesi; ülkeler içindeki ve ülkeler arasındaki eşitsizliklerin giderilmesi; barışçıl, adil ve kapsayıcı toplumların oluşturulması; insan haklarının korunması ve cinsiyet eşitliğinin sağlanması, kadınların güçlendirilmesi ve gezegenin ve doğal kaynaklarının kalıcı bir şekilde korunmasının sağlanması öngörülmektedir. Ayrıca farklı ulusal kalkınma ve kapasiteleri hesaba katarak sürdürülebilir ve kapsayıcı bir ekonomik büyümenin sağlanması ve ortak refah ve insana yakışır çalışma koşullarının oluşturulması da öngörüler arasındadır (BM, 2015).

Sürdürülebilir Kalkınma Hedefleri (SKH) tüm dünyada hızla zemin bulmuş ve önem kazanmıştır. Çünkü günümüz dünyasında ekonomik kalkınma, çevresel sürdürülebilirlik ve sosyal katılma artık tüm ülkelerin kabul ettiği bileşenler haline gelmiştir. Ancak ülkelerin kendilerine ait hedefleri küresel ölçekte bir farklılık oluşturmaktadır. Bu nedenle ilgili alanlarda hedeflere ulaşmanın yolu küresel bir uzlaşmadan geçmektedir ve SKH bu işlevi yerine getirmektedir (Sachs, 2012: 2206).

1960’lı y1llarda sürdürülebilir kalkınma anlayışının temelinde yatan düşünce çevrenin korunması, doğal kaynakların kontrollü olarak kullanılması ve sınırsız ekonomik büyümenin durdurulmasıdır. Ancak küresel ölçekte gelir dağılımındaki adaletsizlik, yoksulluk, açlık ve kötü yaşam koşulları gibi sorunların büyüklüğü sürdürülebilir kalkınma kavramının içerisine insan unsurunun eklenmesine yol açmıştır. Özellikle Brundtland Raporu'ndan sonra sürdürülebilir kalkınmada insana yatırım anlayışının geliştiği görülmektedir. Bu bağlamda temel hak ve özgürlüklerin korunması, cinsiyet eşitliği, demokrasi, iyi bir eğitim, sağlıklı yaşam, dezavantajlı grupların desteklenmesi, kendini gerçekleştirme gibi çok sayıda ilke, temel ihtiyaçlar olarak sürdürülebilir kalkınmanın bir parçası haline getirilmiştir. 


\subsection{Sürdürülebilir Kalkınma Hedefleri Çerçevesinde Engellilerin Güçlendirilmesi}

Modern demokrasilerde hukukun bir gereği olarak bireyler devlete vatandaşlık bağ ile bağlıdır ve bu bağ esasen eşitliği ortaya çıkaran temel statüdür. Bu statünün toplumsal karşılığı aidiyet bağıdır. Teoride gerek devlet, gerekse toplum tüm üyelerine bu perspektiften yaklaşır ve bu bir denge halidir. Ancak gündelik hayatta bu dengeyi tam anlamı ile görmek mümkün değildir. Kaynakların ve gücün dağılımındaki adaletsizlik, bir takım iş ve muamelelerin din, dil, ırk cinsiyet ve bedensellik gibi kıstaslara bağlı olarak farklılaşması, temel hak ve hürriyetlerin kullanılamaması gibi sorunlar büyük veya küçük krizlere neden olur. Bu tip krizler ekonomik olmaktan ziyade sosyal adalet, eşitlik ve dürüstlük krizleridir ve doğrudan sosyal sürdürülebilirliği etkiler. Bu durum doğal olarak ekonomik ve çevresel sürdürülebilirlikteki değişimleri tetikler (Rioux, 2008: 223). Bu değişimlerin negatif zararlarından korunmak için devlete düşen görev vatandaşlık hakkının eşit bir şekilde kullandırılması; topluma düşen görev ise aidiyet duygusunun tüm bireyleri ve grupları kapsayacak şekilde geliştirmesidir.

Engelliliğin hak temelli bir yaklaşımla ele alınması bu noktada önem kazanmaktadır. Ne yazık ki engelliler, gerek küresel, gerekse ulusal ölçekte bu statüden ve toplumsal bağdan en az yararlanan sosyal gruplardan birisidir. Dünya Sağl1k Örgütü (WHO) verilerine göre dünya genelinde engellilerin ayrımcılık, erişebilirlik, yoksulluk, eğitim ve sağlık gibi sorunları devam etmektedir. Üstelik bu sorunlar az gelişmiş ve gelişmekte olan ülkelerde katlanarak artmaktadır, çünkü her bir sorun bir diğerini beslemektedir ve işte tam da bu nedenle engellilik aynı zamanda bir kalkınma sorunudur (WHO, 2011; Brolan, 2016; Tekeli, 2016).

SKH 'nin temelini oluşturan BKH ilan edildiğinde engelliler ve engelli örgütlerinde bir hayal kırıklı̆g 1 yaratmıştır. Çünkü hedeflerde açıkça engellilerden bahsedilmemiş ve hedeflerin ortaya konması noktasında engelli örgütlerinin destek ve teşvikine başvurulmamıştır (Platform Disability and Development Cooperation, 2009; Mitra, 2013; Ghai, 2009). Bununla birlikte 2006 yılında ilan edilen EHS ile BM engelliliği sosyal model bağlamında hak temelli bir yaklaşımla ele almış ve sözleşmenin başlangıç kısmında engelliliğe ilişkin konuların sürdürülebilir kalkınmanın ayrılmaz bir parçası olduğunu kabul etmiştir (BM, 2006). Bu kabul engelliler için büyük bir kazanım olmakla birlikte, BKH içerisindeki yerlerini netleştirmeye yetmemiştir.

BKH'nin oluşturulması sürecinden farklı olarak, 2030 gündemi hazırlanırken BM Kalkınma Grubu çok sesliliğin sağlanması konusunda çeşitli adımlar atmıştır. Bunlardan birisi olan küresel tematik danışma süreci Mayıs 2012 ile Haziran 2013 arasında gerçekleşmiş ve 2015 sonrası tartışma önceliklerini 11 tematik başlığa ayırmıştır. Engellilik bu başlıklardan birisi olmasa da engelliler ve engelli örgütleri her başlıkta tartışmalara katılmış ve yeni hedeflerin çerçevesinin insan hakları ile açıkça desteklenmesi gerektiği savunulmuştur. Engellilerin haklarının 2015 sonrası hedeflerin oluşturulmasına dâhil edilmesine verilen önem, Eylül 2013'te yüksek düzeyli bir Engellilik ve Gelişim Toplantısı ile noktalanmıştır. Toplantı sonucunda Engelli Hakları Sözleşmesinin amaçlarını da destekleyen, eylem odaklı bir kalkınma gündeminin oluşturulması konusunda görüş birliğine varılmıştır (Brolan, 2016: 3-5).

Nihayetinde 2015 yılında açıklanan belgede bu hedef ve amaçların evrensel bir nitelik taşıdığı ve hiç kimsenin dışarıda bırakılmadığı vurgulanmıştır. Ayrıca sürdürülebilir kalkınmanın sosyal, ekonomik ve çevresel boyutları bağlamında bir denge içerisinde ve gelişmiş, gelişmekte olan ve az gelişmiş tüm ülkeleri kapsayacak şekilde gerçekleştirileceği belirtilmiştir (BM, 2015).

İlan edilen 17 hedef ve 169 amacın evrensel ve tüm insanlığ kapsadığ 1 vurgulansa da bunlardan beş tanesinde engellilere somut olarak atıfta bulunulmuşturr. Bu hedefler şunlardır (UN Department of Economic and Social Affairs, 2019a):

- Hedef 4 Nitelikli Eğitim: Bu hedefle kapsayıcı ve eşit kalitede eğitimin ve herkes için yaşam boyu öğrenme fırsatlarının teşvik edilmesi; eğitimdeki cinsiyet eşitsizliklerinin giderilmesi ve engelliler de dâhil olmak üzere kırılgan insanlar için tüm eğitim seviyelerine ve mesleki eğitime eşit erişim sağlanması; buna ek olarak çocuklara, engellilere, toplumsal cinsiyet eşitliğine duyarlı eğitim olanaklarının yaratılması ve geliştirilmesi ve herkes için güvenli, şiddete dayalı olmayan, kapsayıcı ve etkili öğrenme ortamlarının oluşturulması öngörülmektedir.

- Hedef 8 İnsana Yakışır İş ve Ekonomik Büyüme: Herkes için sürekli, kapsayıcı ve sürdürülebilir bir ekonomik büyümeyi, tam ve üretken istihdamı ve insana yaraşır bir işi teşvik edilmesi; gençler ve engelliler de dâhil bütün kadın ve erkeklerin tam ve üretken istihdama ve insana yakışır işlere erişimlerinin sağlanması ve eşit işe eşit ücret ilkesinin tam olarak benimsenmesi öngörülmektedir.

- Hedef 10 Eşitsizliklerin Azaltılması: Engelliler de dâhil olmak üzere herkesin sosyal, ekonomik ve siyasal katılımını desteklemek ve güçlendirmek yoluyla ülkeler içinde ve arasındaki eşitsizliklerin azaltılmaya çalışılması öngörülmektedir. 
- Hedef 11 Sürdürülebilir Şehirler ve Topluluklar: Şehirlerin ve insan yerleşimlerinin kapsayıcı, güvenli ve sürdürülebilir hale getirilmesi; herkes için güvenli, uygun fiyatl, erişilebilir ve sürdürülebilir ulaşım sistemlerine erişiminin sağlanması; karayolu güvenliğinin sağlanması ve özellikle engelliler de dâhil olmak üzere özel önem gösterilmesi gerekenler için toplu taşıma sistemlerinin geliştirilmesi öngörülmektedir.

- Hedef 17 Amaçlar İçin Ortaklıklar: Uygulama araçlarını güçlendirmek ve küresel ortaklıkları canlandırmak için SKH'nin gözlemlenmesi, verilerinin toplanması ve hesap verilebilirliğin sağlanması ve bu bağlamda engellilik alanının da dâhil olduğu yüksek kaliteli, güvenilir, güncel veriye ulaşımın artırılması için tüm devletlerin kapasite geliştirme noktasında teşvik edilmesi öngörülmektedir.

Sayılan bu beş hedefle esasen engellilerin temel sorunları da ortaya konulmaktadır. Bu bağlamda SKH'nin temel felsefesi içerisinde engellilerin güçlendirilmesi için özetle (UN Department of Economic and Social Affairs, 2019b):

- Engellilerin eğitim olanaklarının geliştirilerek, sürdürülebilir ve kaliteli bir eğitim almalarının sağlanmasi;

- İstihdama olanaklarının artırılması ve böylelikle engelli yoksulluğunun da önüne geçilmesi;

- Sağlık imkanlarının artırılması ve yine sağlıkları ile ilgili kararları kendilerinin alabilmeleri;

- Engelli kadın ve kızların hem engellilik, hem de cinsiyet ayrımı nedeniyle maruz kaldıkları muamelenin önlenmesi;

- Bağımsız yaşam olanaklarının sağlanması, her hangi bir kısıtlamaya maruz kalmadan toplumsal hayatın her alanında rahatça hareket edebilmeleri, bir başka ifadeyle yaşadıkları yerlerde mal, hizmet ve mekanlara erişim olanaklarının sağlanması;

- Sosyal, ekonomik ve politik katılımlarının sağlanması, böylelikle başta kendilerini ilgilendiren konular olmak üzere, tüm toplumsal konularda söz sahibi olabilmeleri;

- Belirlenen hedeflerin uygulama olanaklarının artırılması için etkin ve güvenilir bir veri ağının oluşturulması;

- Ve son olarak tüm bunları gerçekleştirmek için gerekli tüm yasal düzenlemelerin yapılması öngörülmektedir.

Engellilere atıf yapılan hedef ve amaçların başarıya ulaşabilmesi için kullanılabilecek iki önemli araç öngörülmektedir (Tekeli, 2016). Bunlardan ilki "ikiz parkur" yaklaşımıdır. Bu yaklaşıma göre SKH çerçevesinde engellilerin güçlendirilmesini desteklemek için bir taraftan onlara özel girişim ve faaliyetlerde bulunulmalı, diğer taraftan ise tüm hedef ve amaçlar için oluşturulan politika ve programların tasarımında, uygulanmasında, izlenmesinde ve denetlenmesinde engellileri de kapsayacak önlemler alınmalıdır (Yeo, 2001: 19-20). İkinci araç ise "kopukluğa izin vermeme politikası" olarak adlandırılmaktadır. Bu yaklaşımın temel savı şudur: Engellilerin sorunlarına yönelik politikaların başarıya ulaşması için tek başına hareket etmek yeterli değildir. Dolayısıyla bir takım kazanımların elde edilebilmesi için ulusal ve uluslararası alanda yer alan çok sayıda kişi, kurum ve kuruluşun bu politikalara destek olması ve işbirliği ile çalışması gerekmektedir. SKH'de belirlenen hedef ve amaçlara ulaşmanın yolu başta engellilerin kendileri olmak üzere çok sayıda aktörün işbirliğinden geçmektedir (Tekeli, 2016: 38).

2030 Gündemi sadece sürdürülebilir kalkınmaya ilişkin bir program ve politika belgesi olmayıp aynı zamanda geleceğe yönelik bir vizyon da belirlemiştir. Bu vizyon içerisinde insan haklarına, insanlık onuruna, hukukun üstünlügüne, adalete, eşitliğe sayg1; ayrımcılığın her türlüsüne bir karşı duruş; bireylerin potansiyellerini geliştirmelerine ve ortak refaha katkıda bulunan bir fırsat eşitliği; toplumun en kırılgan ve savunmasız bireylerinin ihtiyaçlarının karşılandığı adil, hoşgörülü, açık ve sosyal olarak kapsayıcı bir dünya ve tüketim ve üretim kalıplarının ve tüm doğal kaynakların kullanımının sürdürülebilir olduğu, çevrenin korunduğu ve yoksulluğun ve açlığın ortadan kaldırılmasını içeren bir kalkınma anlayışı bulunmaktadır (BM, 2015).

Daha önce de belirtildiği üzere sürdürülebilir kalkınma mantığı içerisinde insan hem bir araç hem de bir amaçtır. Bu nedenle sürdürülebilir bir kalkınmanın gerçekleşebilmesi için öncelikle bireyin güçlendirilmesi, bir başka ifadeyle kendini gerçekleştirme yetisinin kazandırılması gerekmektedir. Bunu sağlamanın başlıca yolu da bireylerin temel haklarını kullanılabilmesi ve ayrım gözetmeden tüm bireylerin firsat eşitliğinden yararlanabilmesinden geçmektedir.

$\mathrm{Bu}$ anlayış çerçevesinde toplumda en fazla güçlendirilmesi gereken grupların başında engelliler gelmektedir. Engellilerin bağımsız ve kaliteli bir hayata sahip olmalarını sağlamak hak temelli yaklaşımın da başlıca hedefidir. Nitekim bu hedef sürdürülebilir kalkınma mantığı paralelinde EHS'de de temel bir ilke 
olarak yer almıştır (Tekeli, 2016). SKH'de engellilere vurgu yapılması bu ilkenin pratiğe aktarılması noktasında önemli bir adım olarak görülmelidir. Çünkü her ne kadar bir yaptırım sistemi bulunmasa da 2030 gündemine taraf olan devletler için bu hedeflere ulaşmak uluslararası bir itibar göstergesidir.

\section{SONUÇ VE ÖNERILER}

İnsan Hakları Evrensel Beyannamesi’nin 28. maddesine göre tüm insanların Bildirgede öngörülen hak ve özgürlüklerin gerçekleşeceği bir toplumsal ve uluslararası düzene hakkı vardır. Ancak engelliler ve bir takım toplumsal gruplar söz konusu olduğunda, bu hak ve özgürlüklerin gerçek hayatta var olabilmeleri için yeniden ulusal ve uluslararası düzenlemelere ihtiyaç duyulmaktadır. Uzun süren mücadeleler ve hak talepleri sonucunda bir takım kazanımlar elde etseler de engelliler, yine de sadece ana akım toplumdan değil, diğer azınlık gruplarından da birçok şekilde ayrılmaktadır (Jaeger ve Bowman, 2005: 10). Güçlendirme kavramına yapılan vurgunun temelinde de bu gerçek yatmaktadır.

Engellilik alanının asli düzenleyicisi ve evrensel ilkelerin belirleyicisi Birleşmiş Milletler'dir. Kuruluş 1975 yılında İnsan Hakları Evrensel Beyannamesi'ne ek olarak yayınladığı Engelli Hakları Bildirgesi'nden bu tarafa yapmış olduğu çalışmalar ve ortaya koyduğu sözleşmelerle engelliliğin bir insan hakları unsuru olarak kabul edilmesini sağlamıştır. Bunun yanında yine bu çalışma ve sözleşmelerde en fazla vurgu yaptı̆̆ konuların başında engellilerin güçlendirilmesi gelmektedir. Çünkü güçlendirme engellilerin kendilerine tanınan hakları kullanabilmelerinin başlıca aracıdır. Nitekim 2006 yılında ilan edilen Engelli Hakları Sözleşmesi’nde de bu tavrını açıkça ortaya koymuştur.

Birleşmiş Milletler Kalkınma Programı tarafından 2015 yılında ilan edilen Sürdürülebilir Kalkınma Hedefleri engellilerin güçlendirilmesine farklı bir boyut kazandırmıştır. Hiç kimsenin dışarıda bırakılmayacağı ilkesinden hareketle, programda beş farklı hedefte engellilere ayrıca yer verilmiştir. Böylelikle bir taraftan engelliler küresel ölçekte bir politikanın parçası olarak kabul edilmiş, diğer taraftan da engellilerin güçlendirilmesi uluslararası bir politik hedef haline getirilmiştir. Ancak, bu olumlu gelişmeye karşın engelliler için her şey tamamlanmış değildir.

Bir takım hakların tanınmasının engellilerin sorunlarını çözmediği, tarihi süreç incelendiğinde açıkça ortaya çıkmaktadır. Bu bağlamda Charlton (2000) tarafından, "Biz Olmadan Bizim Hakkımızda Hiçbir Şey" sloganı ile ortaya konulan güçlendirme yaklaşımı önem kazanmaktadır. Yaklaşım iki temel önermeye dayanmaktadır. Öncelikle, asıl önemli olan engelli bireylerin nasıl bir seçim yaptığı değil, seçimleri nasıl yaptığıdır. İkincisi ise bunun devamı olarak, engelli bireylerin ne yapmak istediğine karar verme eylemlerinin yanında, bu seçime göre hareket edebilme imkânlarının olmasıdır (Stainton, 2005). Bir başka ifadeyle engelli bireyler bir taraftan bağımsız karar verebilmeli, diğer taraftan da verdikleri bu karar doğrultusunda hareket edebilmelidir.

Shakespeare ve Watson (2001) engellilerin gerçek güçlenmesinin ancak gezegenin baskın siyasi ve ekonomik yapılarının yenilenmesiyle gerçekleşebileceğini ileri sürmüştür. Fikre katılmamak mümkün değildir ve hatta bu yapılara engellilik kültürü ve algısı da eklenmelidir. Sürdürülebilir Kalkınma Hedefleri ve engellilik ilişkisi de bu çerçevede değerlendirilebilir. Çünkü hedefler, en azından teoride geleneksel yapılara aykırı bir duruş sergilemektedir. Dolayısıyla, hedefler içerisinde engellilere yapılan vurgular değerli birer kazanımdır. Ancak yine de vurgulamak gerekir ki, teoride elde edilen kazanımlar uygulamaya aktarılmadığı sürece bir anlam ifade etmemektedir.

Sürdürülebilir Kalkınma Hedefleri 2030 yılına kadar devam edecek bir tarih aralığını kapsamaktadır. Belirlenen hedeflere ulaşmak ve engellilerin güçlendirilmesini sağlamak için bu süreçte atılacak ilk adım, engellilerin öncelikle ve mutlaka karar alma süreçlerine katılmalarını sağlamak olmalıdır. Buna ek olarak, ortaya konulan politikaların uygulanması aşamasında gözetim ve denetim mekanizmaları kurulmalı ve bu mekanizmalara da engelliler mutlaka dâhil edilmelidir. Engellilerin söz hakkının olmadığı ya da onlar adına başkaları tarafından oluşturulan politikaların başarıya ulaşma şansı tartışmalıdır. Ayrıca konu sadece engellileri değil tüm toplumu ilgilendirmektedir. Bu nedenle sürece mümkün olduğunca çok aktörün dâhil edilmesi gerekmektedir.

Bu noktada en büyük sorumluluk ve görev politika yapıcılara düşmektedir. Politika yapıcıların engellilik alanını siyasal kaygılardan ve popülist yaklaşımlardan uzak, uzun vadeli planlama ile rasyonel bir şekilde ele almaları gerekmektedir. Sürdürülebilir kalkınmanın altında yatan temel mantık bu günden geleceğin inşa edilmesidir. Engellilerin güçlendirilmesi de bu mantıkla ele alınmalıdır. 


\section{KAYNAKÇA}

Adams, W. M. (2009), Green Development Environment and Sustainability in a Developing World, Routledge, Oxon.

Anand, S., ve Sen, A. (1994), Sustainable Human Development: Concepts and Priorities, Human Development Report Office , Human Development Occasional Papers (1992-2007), United Nations Development Programme.

Anand, S., ve Sen, A. (2000), "The Income Component of the Human Development Index", Journal of Human Development, 1(1), s. 83-106.

Bagenstos, S. R. (2009), Law and the Contradictions of the Disability Rights Movement, Yale University Press, Connecticut.

Barbier, E. B. (1987), “The Concept of Sustainable Economic Development”, Environmental Conservation, 14(2), s. 101 110.

Barnes, C. (2004), "Reflections on Doing Emancipatory Disability Research”, (Ed.) J. Swain, S. French, C. Barnes, ve C. Thomas içinde, Disabling Barriers-Enabling Environments (s. 47-53), SAGE Publications, London.

Barnes, C. (2012), "Understanding The Social Model of Disability Past Present and Future", (Ed.) N. Watson, A. Roulstone, ve C. Thomas içinde, Routledge Handbook of Disability Studies (s. 12-29), Routledge, Oxon.

Barnes, C., ve Mercer , G. (2003), Disability: Key Concepts, Polity Press, Cambridge.

Barnes, C., ve Mercer, G. (2006), Independent Futures: Creating User-Led Disability Services in a Disabling Society, The Policy Press, Bristol.

Beaulaurier, R. L., ve Taylor, S. H. (2007), "Social Work Practice with People with Disabilities in The Era of Disability Rights", (Ed.) A. O. Dell, ve P. W. Power içinde, Psychological and Social Impact of Illness and Disability (s. 5375), Springer Publishing, New York.

Berber, M. (2006), İktisadi Büyüme ve Kalkınma, Derya Kitabevi, Trabzon.

Beresford, P. (2012), "Psychiatric System Survivors: An Emerging Movement", (Ed.) N. Watson, A. Roulstone, ve C. Thomas içinde, Routledge Handbook of Disability Studies (s. 151-164), Rotledge, Oxon.

Bickenbach, J. E. (2012), "The International Classification of Functioning, Disability and Health and Its Relationship to Disability Studies”, (Ed.) N. Watson, A. Roulstone, ve C. Thomas içinde, Routledge Handbook of Disability Studies (s. 51-66), Routledge, Oxon.

BM. (1973), Report of The United Nations Conference on The Human Environment Stockholm 1972, United Nations Publication, New York.

BM. (2000), "United Nations Millennium Declaration", erişim tarihi 10.08.2019 https://undocs.org/A/RES/55/2.

BM. (2006), "Convention on the Rights of Persons with Disabilities", erişim tarihi 21.08.2019 https://undocs.org/A/RES/61/106.

BM. (2015), "Transforming Our World: The 2030 Agenda for Sustainable Development", erişim tarihi 08.07.2019, https://undocs.org/A/RES/70/1.

Brisenden, S. (1986), "Independent Living and the Medical Model of Disability”, Disability, Handicap ve Society, 1(2), s. $173-178$.

Brolan, C. E. (2016), "A Word of Caution: Human Rights, Disability, and Implementation of the Post-2015 Sustainable Development Goals", Laws, 5(22), s. 1-18.

Burcu, E. (2007), Türkiye'de Özürlü Birey Olma: Temel Sosyolojik Özellikleri ve Sorunları Üzerine Bir Araştırma, Hacettepe Üniveristesi Yayınları, Ankara.

Charlton, J. I. (2000), 'Nothing About Us Without Us' Disability Oppression and Empowerment, University of California Press, California.

Cooper, J. (2000), "Improving the Civil Rights of People with Disabilities Through International Law", (Ed.) J. Cooper içinde, Law Rights and Disability (s. 59-81), Jessica Kingsley Publishers, London.

Davis, L. J. (2006). "Introduction", (Ed.) L. J. Davis içinde, The Disability Studies Reader (s. vx-xviii), Routledge, New York.

Drake, R. F. (1999). Understanding Disability Policies, Palgrave Macmillan, London.

Fazil, Q., Wallace, L. M., Singh, G., Ali, Z., ve Bywaters, P. (2004), "Empowerment and Advocacy: Reflections on Action Research with Bangladeshi and Pakistani Families Who Have Children with Severe Disabilities", Health and Social Care in the Community, 12(5), s. 389-397.

Gadacz, R. R. (1994), Re-Thinking Disability, The University of Alberta Press, Alberta.

Gaffney, O. (2014), "Sustainable Development Goals Improving Human and Planetary Wellbeing", Global Change, (82), s. $20-23$.

Ghai, A. (2009), "Disability and the Millennium Development Goals: A Missing Link", Journal of Health Management, $11(2)$, s. 279-295.

Ghosh, N. (2012), "Disabled Definitions, Impaired Policies:Reflections on Limits of Dominant Concepts of Disability", Occasional Paper 34. Institute of Development Studies Kolkata.

Goodley, D. (2011), Disability Studies An Interdisciplinary Introduction, SAGE Publications, London.

Griffiths, M., Mannan, H., ve MacLachlan, M. (2009), "Empowerment, Advocacy and National Development Policy: A Case Study of Disabled Peoples' Organizations in Bolivia”, (Ed.) M. MacLachlan, ve L. Swartz içinde, Disability ve International Development (s. 105-118), Springer, London. 
Haapanen, L., ve Tapio, P. (2016), "Economic Growth as Phenomenon,Institution and Ideology: A Qualitative Content Analysis of the 21 st Century Growth Critique", Journal of Cleaner Production, (112), s. 3492-3503.

Hansen, C., ve Sait, W. (2011), "We too are disabled: Disability Grants and Poverty Politics in Rural South Africa”, (Ed.) A. H. Eide, ve B. Ingstad içinde, Disability and Poverty A Global Challenge (s. 93-119), Policy Press, Bristol.

ICLEI. (2015), "From MDGs to SDGs: What are the Sustainable Development Goals?", erişim tarihi 27.07.2019, https://www.local2030.org/.

Ingstad, B., ve Eide, A. H. (2011), "Introduction”, (Ed.) A. H. Eide, ve B. Ingstad içinde, Disability and Poverty A Global Challenge (s. 1-15), Policy Press, Bristol.

Jaeger, P. T., ve Bowman, C. A. (2005), Understanding Disability, Greenwood Publishing, Connecticut.

Lee, T. M. (2005), "Multicultural Citizenship: The Case Of The Disabled”, (Ed.) D. Pothier, ve R. Devlin içinde, Critical Disability Theory: Essays in Philosophy, Politics, Policy and Law (s. 87-106), UBC Press, Vancouver.

Linton, S. (2006). "Reassigning Meaning", (Ed.) L. J. Davis içinde, The Disability Studies Reader (s. 161-173), Routledge, New York.

Meadows, D. H., Meadows, D. L., Randers, J., ve Behrens III, W. W. (1972), Limits To Growth, Universe Books, New York.

Mitra, S. (2013), “A Data Revolution for Disability-Inclusive Development”, Lancet, (1), 178-179.

Muyinda, H., ve Whyte, S. R. (2011), "Displacement, Mobility and Poverty in Northern Uganda”, (Ed.) A. H. Eide, ve B. Ingstad içinde, Disability and Poverty A Global Challenge (s. 119-137), Policy Press, Bristol.

Page, N., ve Czuba, C. E. (1999), "Empowerment: What is it?", Journal of Extension, 37(5), s. 1-5.

Peterson, W. C. (1994), Gelir İstihdam ve Ekonomik Büyüme, Çev. T. Güllap, Atatürk Üniversitesi Yayınları, Erzurum.

Pfeiffer, D. (2007), “The Disability Paradigm”, (Ed.) A. E. Dell, ve P. W. Power içinde, Psychological and Social Impact of Illness and Disability (s. 7-11), Springer Publishing Company, New York.

Platform Disability and Development Cooperation. (2009), Disability and The Millenium Development Goals, PHOS, Brussels.

Rioux, M. H. (2008), "Disability, Citizenship and Rights in a Changing World”, (Ed.) C. Barnes, M. Oliver, ve L. Barton içinde, Disability Studies Today (s. 210-228), Blackwell Publishers, Massachusetts.

Sachs, J. D. (2012), "From Millennium Development Goals to Sustainable Development Goals", Lancet, (379), s. 22062211.

Shakespeare, T. (2006), “The Social Model of Disability”, (Ed.) L. J. Davis içinde, The Disability Studies Reader (s. $197-$ 205), Routledge, New York.

Shakespeare, T., ve Watson, N. (2001), "Making the Difference Disability, Politics, and Recognition”, (Ed.) G. L. Albrecht, K. Seelman, ve M. Bury içinde, Handbook of Disability Studies (s. 546-565), Sage Publications, California.

Siebers, T. (2006), "Disability in Theory: Disability in Theory to the New Realism of the Body", (Ed.) L. J. Davis içinde, The Disability Studies Reader (s. 173-185), Routledge, New York.

Soubbotina, T. P. (2004), Beyond Economic Growth An Introduction to Sustainable Development, Second Edition b., The World Bank, Washington D.C.

Stainton, T. (2005), "Empowerment and The Architecture of Rights Based Social Policy", Journal of Intellectual Disabilities, 9(4), s. 289-298.

Streeten, P. (1994), "Human Development: Means and Ends", The American Economic Review, 84(2), s. $232-237$.

Swartz, L., ve MacLachlan, M. (2009), "From the Local to the Global: The Many Contexts of Disability and International Development”, (Ed.) M. MacLachlan, ve L. Swartz içinde, Disability ve International Development (s. 1-13), Springer, London.

Tekeli, D. (2016), “Engelliliği Kapsayıcı Kalkınma: Neden söz ediyoruz?”, erişim tarihi 08.18.2019, http://panel.stgm.org.tr/vera/app/var/files/e/n/engelliligi-kapsayici-kalkinma.neden-soz-ediyoruz_.pdf.

Thomas, C. (2008), "Disability Theory: Key Ideas,Issues and Thinkers”, (Ed.) Barnes Colin, Oliver Mike, ve L. Barton içinde, Disability Studies Today (s. 38-58), Blackwell Publishers, Massachusetts.

UN Department of Economic and Social Affairs. (2018), “2018 International Day of Persons with Disabilities”, erişim tarihi 06.11.2019, https://www.un.org/development/desa/disabilities/news/dspd/idpd.html.

UN Department of Economic and Social Affairs. (2019a), "Sustainable Development Goals and Disability", erişim tarihi 12.08.2019, https://www.un.org/development/desa/disabilities/about-us/sustainable-development-goals-sdgsand-disability.html.

UN Department of Economic and Social Affairs. (2019b), Disability and Development Report 2018, United Nations, New York.

UN Department of Economic and Social Affairs. (2019c), “The Invisibility of Disability Why Disability Statistics Matter”, erişim tarihi 23.07.2019, https://www.un.org/development/desa/publications/graphic/disability-statistics.

UNDP. (1990), Human Development Report 1990, Oxford University Press, New York.

UNDP. (2016), From The MDGs to Sustainable Development For All, UNDP, New York.

United Nations.(1948), “The Universal Declaration of Human Rights”, erişim tarihi 29.08.2019, https://www.un.org/en/udhrbook/pdf/udhr_booklet_en_web.pdf.

UPIAS. (1976), Fundamental Principles of Disability. London. 
WCDE. (1987), Report of the World Commission on Environment and Development: Our Common Future. United Nations.

WHO. (1993), International Classification of Impairments Disabilities and Handicaps, World Health Organization, Geneva.

WHO. (2011), World Report on Disability, WHO Publications, Geneva.

Yeo, R. (2001). Chronic Poverty and Disability. Working Papper No. 4: Chronic Poverty Research Centre. 